\title{
Dampak Pandemi Covid-19 Terhadap Dunia Pendidikan
}

\author{
Matdio Siahaan \\ Fakultas Ekonomi dan Bisnis; Universitas Bhayangkara Jakarta Raya; Jl. Raya \\ Perjuangan, Marga Mulya, Bekasi Utara, Jawa Barat 17121. Telp: 021-88955882, 889955883; \\ e-mail: matdio.siahaan@dsn.ubharajaya.ac.id \\ * Korespondensi: email: matdio.siahaan@dsn.ubharajaya.ac.id
}

\begin{abstract}
s
Indonesia is one of the countries infected with the Covid-19 pandemic. Corona virus 2019 (COVID-19) is an infectious disease caused by acute corona virus 2 respiratory syndrome (SARS-CoV-2). So that the impact on the community and students can not meet directly on campus or in public places. Based on Nielsen's research entitled "Race Against the Virus, the Indonesian Consumer Response towards COVID-19" revealed that as much as $50 \%$ of Indonesian people began to reduce activities outside the home, and $30 \%$ of them said that they planned to shop more frequently online. Likewise, teaching and learning activities are carried out from home and even work is done from home with the aim of reducing Covid-19 epidemic.

Key Words: Pandemic Covid-19, Distance Learning/OnIne, Education,

Abstrak

Indonesia merupakan salah satu negara yang terinfeksi pandemi Covid-19. Penyakit Corona virus 2019 (COVID-19) adalah penyakit menular yang disebabkan oleh sindrom pernapasan akut corona virus 2 (SARS-CoV-2). Sehingga berdampak kepada Masyarakat dan Mahasiswa tidak bisa bertemu langsung di kampus atau di tempat umumu. Berdasarkan Riset Nielsen yang bertajuk "Race Against the Virus, Indonesian Consumer Response towards COVID-19" mengungkapkan bahwa sebanyak 50\% masyarakat Indonesia mulai mengurangi aktivitas di luar rumah, dan $30 \%$ di antaranya mengatakan bahwa mereka berencana untuk lebih sering berbelanja online. Begitu juga kegiatan proses belajar mengajar dilaksanakan dari rumah bahkan bekerja pun dilakukan dari rumah dengan tujuan agar bisa mengurangi penularan Covid-19.
\end{abstract}

Kaca Kunci: Penularan Covid-19, Belajar Jarak Jauh, Pendidikan.

\section{Pendahuluan}

Sudah hampir tiga bulan stay at home (tinggal dirumah) dan Work From Home (bekerja dari rumah) serta E-Learning bagi Mahasiswa sesuai dengan program pemerintah untuk memutus rantai pandemi covid-19 (Corona Virus Disease) yang sangat mematikan orang kalau sudah kena virus tersebut, Bukan hanya di Indonesia tapi diseluruh dunia. Banyak menafsirkan bahwa Covid-19 ini adalah sebagai teguran kepada umat manusia agar semua kembali peduli terhadap ciptaan Tuhan, Indonesia merupakan salah satu negara yang terinfeksi pandemi Covid-19. Penyakit Corona virus 2019 (COVID-19) adalah penyakit menular yang disebabkan oleh sindrom pernapasan akut corona virus 2 (SARS-CoV-2). Penyakiti ini pertama kali diidentifikasi pada Desember 2019 di Wuhan, ibukota provinsi Hubei China, dan sejak itu menyebar secara global, mengakibatkan pandemic korona virus 2019-20 yang sedang 
Submitted: 12 Juni 2020; Revised: 3 Juli 2020; Accepted: 24 Juli 2020; Published: 31 Juli 2020

berlangsung. Gejala umum termasuk demam, batuk, dansesaknapas. Gejala lain mungkin termasuk nyeriotot, diare, sakit tenggorokan, kehilangan bau, dan sakit perut. Sementara sebagian besar kasus mengakibatkan gejala ringan, beberapa berkembang menjadi pneumonia virus dan kegagalan multi-organ. Pada 5 April 2020, lebih dari 1,2 juta kasus telah dilaporkan di lebih dari dua ratus Negara dan wilayah, mengakibatkan lebih dari 64.700 kematian. Lebih dari 246.000 orang telah pulih.

Manusia merupakan mahluk sosial yang memungkinkan saling berinteraksi secara langsung sehingga tingkat penyebaran pandemi Covid-19 semakin pesat. Sehingga Pemerintah tengah menyiapkan aturan karantina kewilayahan atau lockdown untuk memutuskan matarantai penyebaran virus corona atau COVID 19. Menurut Mahfud, karantina kewilayahan diatur dalam aturan undang-undang nomor 6 tahun 2018 tetang kekarantina kesehatan. Bertujuan membatasi perpindahan orang membatasi kerumunan orang, membatasi gerakan orang demi keselamatan bersama. Sebagian besar orang yang terinfeksi COVID 19, akan mengalami penyakit pernapasan ringan hingga sedang, bahkan menyebabkan sulit bernafas sehingga meninggal. Virus ini bisa sembuh dengan sendirinya karena imunitas tubuh. Namun orang tua lebih rentan terkena virus ini. Apalagi orang tua yang memiliki penyakit diabetes. Pernapasan kronis dan kanker.

Karena adanya virus ini, aktivitas masyarakat di berbagai Negara jadi terganggu sehingga membuat masyarakat di dunia harus tetap diam dirumah untuk memutus mata tantai virus corona agar tidak semakin menyebar. Lalu perekonomian di berbagai dunia juga semakin menurun karena adanya virus ini. Asian Development Bank (ADB) memprediksi pertumbuhan ekonomi nasional hanya sebesar $2,5 \%$ pada tahun 2020 atau terpangkas setengahnya setelah pada tahun 2019 tumbuh $5,0 \%$. Hal ini disebabkan oleh pandemi virus corona yang menjangkiti berbagai wilayah nusantara.

\section{Metode Penelitian}

Metode penelitian yang dilakukan yaitu: a) Observasi: Dalam penelitian, penulis melakukan pengamatan secara langsung mengenai dampak dan ikut merasakan dari Pandemi Covid-19 ini pada saat sekarang ini. b) Literatur: Dalam penulisan ini Penulis banyak Membaca dan Mendengarkan perkembangan pandemi Covid-19 dari Media Sosial maupun dari informasi televise yang terus di update oleh kantor Gugus tugas Covid-19.

\section{Hasil dan Pembahasan}

\subsection{Dampak Pandemic Covid-19}

Pada saat ini disrupsi teknologi terjadi di dunia Pendidikan, pembelajaran tatap muka yang dilaksanakan 100 persen di sekolah, secara tiba-tiba mengalami perubahan yang sangat drastis. Dan, tak bisa dipungkiri di atas 50 persen pelajar dan mahasiswa berasal dari masyarakat berpenghasilan rendah dan menengah. 
Akibat dari pandemi covid-19 ini, menyebabkan diterapkannya berbagai kebijakan untuk memutus mata rantai penyebaran virus covid-19 di Indonesia. Upaya yang dilakukan oleh pemerintah di Indonesia salah satunya dengan menerapkan himbauan kepada masyarakat agar melakukan physical distancing yaitu himbauan untuk menjaga jarak diantara masyarakat, menjauhi aktivitas dalam segala bentuk kerumunan, perkumpulan, dan menghindari adanya pertemuan yang melibatkan banyak orang. Upaya tersebut ditujukan kepada masyarakat agar dapat dilakukan untuk memutus rantai penyebaran pandemi Covid-19 yang terjadi saat ini.

Pemerintah menerapkan kebijakan yaitu Work From Home (WFH). Kebijakan inimerupakan upaya yang diterapkan kepada masyarakat agar dapat menyelesaikan segala pekerjaan di rumah. Pendidikan di Indonesia pun menjadi salah satu bidang yang terdampak akibat adanya pandemi Covid-19 tersebut. Dengan adanya pembatasan interaksi, Kementerian Pendidikan di Indonesia juga mengeluarkan kebijakan yaitu dengan meliburkan sekolah dan mengganti proses Kegiatan Belajar Mengajar (KBM) dengan menggunakan sistem dalam jaringan (daring). Dengan menggunakan sistem pembelajaran secara daring ini, terkadang muncul berbagai masalah yang dihadapi oleh siswa dan guru, seperti materi pelajaran yang belum selesai disampaikan oleh guru kemudian guru mengganti dengan tugas lainnya. Hal tersebut menjadi keluhan bagi siswa karena tugas yang diberikan oleh guru lebih banyak.

Permasalahan lain dari adanya sistem pembelajaran secara online ini adalah akses informasi yang terkendala oleh sinyal yang menyebabkan lambatnya dalam mengakses informasi. Siswa terkadang tertinggal dengan informasi akibat dari sinyal yang kurang memadai. Akibatnya mereka terlambat dalam mengumpulkan suatu tugas yang diberikan oleh guru. Belum lagi bagi guru yang memeriksa banyak tugas yang telah diberikan kepada siswa, membuat ruang penyimpanan gadget semakin terbatas. Penerapan pembelajaran online juga membuat pendidik berpikir kembali, mengenai model dan metode pembelajaran yang akan digunakan. Yang awalnya seorang guru sudah mempersiapkan model pembelajaran yang akan digunakan, kemudian harus mengubah model pembelajaran tersebut.

Di balik masalah dan keluhan tersebut, ternyata juga terdapat berbagai hikmah bagi pendidikan di Indonesia. Diantaranya, siswa maupun guru dapat menguasai teknologi untuk menunjang pembelajaran secara online ini. Di era disrupsi teknologi yang semakin canggih ini, guru maupun siswa dituntut agar memiliki kemampuan dalam bidang teknologi pembelajaran. Penguasaan siswa maupun guru terhadap teknologi pembelajaran yang sangat bervariasi, menjadi tantangan tersendiri bagi mereka. Dengan adanya kebijakan Work From Home (WFH), maka mampu memaksa dan mempercepat mereka untuk menguasai teknologi pembelajaran secara digital sebagai suatu kebutuhan bagi mereka. Tuntutan kebutuhan tersebut, membuat mereka dapat mengetahui media online yang dapat menunjang sebagai pengganti pembelajaran di kelas secara langsung, tanpa mengurangi kualitas materi pembelajaran dan target pencapaian dalam pembelajaran. Berbagai media pembelajaran jarak jauh pun dicoba dan digunakan. Sarana yang dapat digunakan sebagai media pembelajaran online antara lain, e-learning, aplikasi zoom, google classroom, youtube, maupun media sosial whatsapp. Sarana- 
Submitted: 12 Juni 2020; Revised: 3 Juli 2020; Accepted: 24 Juli 2020; Published: 31 Juli 2020

sarana tersebut dapat digunakan secara maksimal, sebagai media dalam melangsungkan pembelajaran seperti di kelas. Dengan menggunakan media online tersebut, maka secara tidak langsung kemampuan menggunakan serta mengakses teknologi semakin dikuasai oleh siswa maupun guru.

Setelah pendidik mampu menguasai berbagai sarana pembelajaran online, maka akan tercipta pemikiran mengenai metode dan model pembelajaran lebih bervariasi yang belum pernah dilakukan oleh pendidik. Misalnya, guru membuat konten video kreatif sebagai bahan pengajaran. Dalam hal ini, guru lebih persuasif karena membuat peserta didik semakin tertarik dengan materi yang diberikan oleh guru melalui video kreatif tersebut. Peserta didik tentu akan dapat memahami apa yang dijelaskan oleh guru melalui video kreatif yang dibuat oleh guru tersebut. Sehingga dengan adanya penerapan model pembelajaran di rumah ini, membuat siswa tidak merasa bosan dalam mengikuti pembelajaran secara online.

Penggunaan teknologi dalam menyelesaikan tugas pada siswa, juga dapat menimbulkan kreativitas dikalangan siswa dalam mengembangkan pengetahuan yang telah mereka miliki. Dengan metode pembelajaran yang bervariasi dari guru, mereka dapat menciptakan suatu produk pembelajaran kreatif yang dapat mengembangkan pemikiran melalui analisis mereka sendiri, tanpa keluar dari pokok bahasan materi yang telah disampaikan oleh guru. Adanya pandemi covid-19 juga memberikan hikmah yang lainnya. Pembelajaran yang dilakukan di rumah, dapat membuat orang tua lebih mudah dalam memonitoring atau mengawasi terhadap perkembangan belajar anak secara langsung. Orang tua lebih mudah dalam membimbing dan mengawasi belajar anak dirumah. Hal tersebut akan menimbulkan komunikasi yang lebih intensif dan akan menimbulkan hubungan kedekatan yang lebih erat antara anak dan orang tua. Orang tua dapat melakukan pembimbingan secara langsung kepada anak mengenai materi pembelajaran yang belum dimengerti oleh anak. Dimana sebenarnya orang tua adalah institusi pertama dalam pendidikan anak. Dalam kegiatan pembelajaran secara online yang diberikan oleh guru, maka orang tua dapat memantau sejauh mana kompetensi dan kemampuan anaknya. Kemudian ketidakjelasan dari materi yang diberikan oleh guru, membuat komunikasi antara orang tua dengan anak semakin terjalin dengan baik. Orang tua dapat membantu kesulitan materi yang dihadapi anak.

Hikmah selanjutnya yaitu penggunaan media seperti handphone atau gadget, dapat dikontrol untuk kebutuhan belajar anak. Peran orang tua semakin diperlukan dalam melakukan pengawasan terhadap penggunaan gadget. Hal tersebut memberikan dampak yang positif bagi anak, dalam memanfaatkan teknologi untuk hal-hal yang bermanfaat. Anak cenderung akan menggunakan handphone untuk mengakses berbagai sumber pembelajaran dari tugas yang diberikan oleh guru. Sehingga akan membuat anak menghindari penggunaan gadget pada halhal kurang bermanfaat atau negatif.

Walaupun pendidikan di Indonesia ikut terdampak adanya pandemi covid-19 ini, namun dibalik semua itu terdapat hikmah dan pelajaran yang dapat diambil. Adanya kebijakan pemerintah untuk melakukan pembelajaran jarak jauh melalui online, maka dapat memberikan 
manfaat yaitu meningkatkan kesadaran untuk menguasai kemajuan teknologi saat ini dan mengatasi permasalahan proses pendidikan di Indonesia.

\subsection{Langkah-Langkah Tindakan}

\section{a) Pemerintah}

Pemerintah pada saat ini sudah berubah kebijakan dari Pembatasan Sosial Berskala Besar (PSBB) menjadi kondisi NEW NORMAL dengan protokoler yang ketat berdasarkan kebijakan social distancing atau physical distancing yang menjadi dasar pelaksanaan belajar dari rumah dengan pemanfaatan teknologi sebagai media pembelajaran yang secara tiba-tiba, tidak heran membuat tenaga pendidik dan peserta didik kaget termasuk orang tua. Dari berbagai keluhan diatas dapat menjadi tantangan bagi para tenaga pendidik, bagaimana cara mereka tetap memberikan motivasi kepada peserta didik dalam melakukan pembelajaran online ini. Seorang tenaga pendidik harus mampu menginovasi dirinya dan peserta didik, maksudnya guru/dosen disini harus mampu membangkitkan semangat motivasi peserta didik dengan penjelasan materi dan tugas yang berbeda dengan berbagai metode belajar yang menarik.

Saat ini sangat diperlukan media social pemerintah seperti TVRI bergeser fungsi dari hiburan menjadi ruang pembelajaran secara nasional dan tv swasta, bisa dimanfaatkan agar anak didik makin mendapatkan ilmu yang banyak dengan kualitas yang sama dikota maupun di desa. Generasi milenial, sekarang mungkin sudah lebih aman belajar dirumah, daripada repot dengan segudang peraturan jika keluar rumah. Oleh karena itu pemerintah segera bertindak memberikan kelonggaran untuk memberikan pulsa murah untuk pelajar, agar mereka bisa online setiap saat, ini juga sekaligus mengurangi beban orang tua. Karena bagi kaum milenial pulsa/paket lebih penting daripada makan atau jajan lainnya.

\section{b) Pendidik/Dosen/Akademisi}

Sebagai seorang pendidik harus terus bertanggung jawab untuk mengembangkan Tridarma Perguruan Tinggi agar tercapai targetnya untuk menyampaikan tugas pengajaran, dimana mata kuliah harus selesai dilaknakan sesuai waktu yang sudah ditentukan, Dengan berbagai cara bisa dilakukan menyampaikan materi secara online, dan pertanyaan dan kuis yang diberikan dan dibicarakan dalam forum diskusi. Begitu juga dengan Penelitian yang akan dilakukan untuk mencari solusi masalah yang dihadapi oleh masyarakat seperti masa pandemi covid-19 agar masyarakat merasakan hasil dari penelitian yang dilakukan oleh pihak akademisi sampai benar-benar bisa dirasakan masyarakat manfaat dari solusi yang disampaikan oleh pihak akademisi. Pengabdian Kepada Masyarakat juga seharusnya bisa dilaksanakan walaupun masa Pembatasan Sosial Berskala Besar ini, dengan menerapkan Social Distancing dan Physikal Distancing mungkin tidak maksimal yang dicapai tapi minimal sudah ikut serta mengurangi beban masyarakat agar mereka bangun dari keterpurukan ini.

$\mathrm{Hal}$ inilah yang terus digali lebih dalam oleh pihak akademisi, tentunya terus difasilitasi oleh pihak kampus, atau membantu pemerintah untuk menyalurkan bantuan social atau ikut serta membantu pemerintah untuk memonitor apakah bansos tersebut sampai kepada pihak yang patut menerima bantuan tersebut dengan mendata ulang. 


\section{c) Orang tua}

Dari sisi orang tua memang paling berat, karena memikirkan biaya untuk kehidupan sehari-hari ditambah harus memperhatikan mendampingi anak-anak untuk belajar, mungkin harus menambah biaya untuk pulsa, agar anak-anak tetap jalan belajar dengan daring. Orang tua harus mampu bertransformasi dan berdaptasi terlebih dahulu, sehingga orang tua mampu menjadi pendamping atau mentor perubahan bagi anak-anaknya di rumah. Dimasa pandemi ini menjadi sebuah peluang untuk menyadarkan setiap orang tua bahwa beban pendidikan anak tidak bisa hanya diserahkan pada guru/dosen semata. Pembelajaran sesungguhnya merupakan proses pengubahan sikap dan perilaku seseorang melalui upaya pengajaran dan pelatihan. Orang tua yang menjadi mentor dan pendamping di rumah merupakan role model perubahan sikap bagi siswa dalam berperilaku dan menghadapi permasalahan saat ini. Orang tua harus mampu belajar kembali bersama anak-anak di rumah. Sekaligus, menanamkan pola berpikir yang positif sehingga menghadapi pandemi ini, sebagai sebuah pola hidup baru yang harus dibiasakan untuk dijalani karena menjadi New Normal walaupun dengan protokoler yang ketat.

\section{d) Anak Didik}

Dengan pemerintah meliburkan sekolah untuk mencegah meluasnya penyebaran Covid-19. mahasiswa kini diwajibkan belajar di rumah. Kebijakan ini sudah berlaku hampir tiga bulan lebih. mahasiswa mulai jenuh bahkan mengeluh dengan banyaknya tugas dari Dosen, sehingga mereka rata-rata meminta waktu mundur untuk menyelesaikan tugas - tugas tersebut. Masalahnya banyak ada listrik mati, kendala internet, paket habis, jadi sebagai Dosen sering berpihak dengan kondisi sulit seperti ini. Sementara mahasiswa kurang focus juga karena dirumah sudah bosan, dan sering badtime karena berjam-jam duduk didepan computer atau handphonenya.

Banyak juga mahasiswa merasa stres karena di saat belajar, mahasiswa juga masih harus membantu orang tua mengurusi pekerjaan rumah, masak, membereskan rumah dan lainlain, karena tidak enak melihat orang tua mengerjakan hal tersebut.ini disampaikan oleh mahasiswa saya ketika diskusi via Whatapp. Permintaan dari Mahasiswa agar tugas jangan terlalu banyak diberikan oleh Dosen, kalau ada tugas sebaiknya diberikan waktu agak longgar agar mereka tetap bisa focus dan imun tubuh mereka tetap terjaga, soalnya kalau beban terlalu berat maka mereka mengerjakan seperti asal-asalan. Karena mereka perlu juga waktu untuk istirahat agar mereka tetap konsentrasi supaya ilmu yang diterima bisa meresap. Yang mereka sukai adalah menjawab soal-soal yang memberikan mereka hiburan, agar mereka tertarik membaca atau berupa video/ppt. Sebenarnya mereka juga ingin membangun disiplin yang tinggi di rumah. Dengan terbentuknya pola pikir yang siap unggul dalam menghadapi kompleksitas dan kerumitan yang akan muncul pada masa mendatang, menjadi bekal penting bagi setiap individu. Sadar tidak sadar bahwa persaingan makin ketat dimasa yang akan datang. Masa pandemi covid-19 ini akan masuk menjadi new normal, walau mahasiswa masih penuh keterbatasan mereka tetap berusaha keras demi masa depan yang lebih cerah. 


\section{Kesimpulan}

Walaupun banyak tenaga pendidik, peserta didik maupun masyarakat yang belum siap menghadapi era revolusi industry 4.0, pembelajaran daring di tengah pandemi covid-19 ini seakan-akan memaksa semua manusia harus siap terhadap perkembangan teknologi saat ini. Jika dilihat dalam perspektif sosiologi, kebijakan ini merupakan langkah yang tepat dilakukan dalam kondisi seperti ini. Seperti ada percepatan agar masyarakat lebih cepat maju, dengan teknologi internet sekarang, misalnya dengan belanja dengan system online, lebih disukai masyarakat dan mengurangi waktu dan biaya transfort, apalagi masa covid-19. Karena lebih aman dan sehat. Kita harapkan semoga pandemi covid-19 lekas berakhir, semua warga bangsa senantiasa sehat dan proses kehidupan dapat berjalan normal kembali dengan menciptakan manusia manusia baru yang memiliki pola pikir positif yang sarat solidaritas sosial,

\section{Ucapan Terima Kasih}

Secara khusus rasa terimakasih tersebut kami sampaikan kepada;

1. Irjen.Pol. (Purn) Dr. Drs.H. Bambang Karsono, SH., MM. selaku Rektor Universitas Bhayangkara Jakarta Raya yang telah memberikan arahan dan semangat bagi para Dosen untuk terus melakukan Penelitian dan Penulisan untuk kemajuan di Universitas Bhayangkara Jakarta Raya.

2. Dr. Istianingsih, selaku Dekan Fakultas Ekonomi Universitas Bhayangkara Jakarta Raya yang telah menyetujui untuk melakukan Penulisan Naskah Tentang Pandemi Covid-19.

3. Ir. Djuni Thamrin, Ph. D, selaku Kepala Lembaga Penelitian, Pengabdian Masyarakat dan Publikasi yang telah banyak memberikan arahan serta masukan dalam penyerpurnaan Penulisan Naskha tentang Pandemi Covid-19.

4. Herlawati, S.Si., M.M., M. Kom, selaku Kepala Bidang Publikasi \& Inovasi Ubhara Jaya yang telah memberikan arahan serta masukan dalam penyempurnaan naskah tulisan ini.

\section{Daftar Pustaka}

Ayu Kurniawati, K. R., Santosa, F. H., \& Bahri, S. (2020). Sosialisasi Hidup Sehat di Tengah Wabah Virus Corona. JPMB: Jurnal Pemberdayaan Masyarakat Berkarakter. https://doi.org/10.36765/jpmb.v3i1.225

Mufid Luthfi, M. (2020). Menelusuri Bagaimana Dampak Virus Corona (COVID-19) Bagi Perekonomian Indonesia. Idcloudhost.Com.

Rahmadia, S., Febriyani, N., Kuala, U. S., Islam, J. E., \& Kuala, U. S. (2020). Dampak covid-19 terhadap ekonomi. Jurnal Ekonomi Islam(JE Islam).

Siregar, P. P., \& Zahra, A. H. (2020). Bencana Nasional Penyebaran COVID-19 sebagai Alasan Force Majeure, Apakah Bisa? Direktorat Jenderal Kekayaan Negara Kementerian Keuangan.

Watnaya, A. kusnayat, Muiz, M. hifzul, Nani Sumarni, Mansyur, A. salim, \& Zaqiah, Q. yulianti. 
Submitted: 12 Juni 2020; Revised: 3 Juli 2020; Accepted: 24 Juli 2020; Published: 31 Juli 2020

(2020). Pengaruh Teknologi Pembelajaran Kuliah Online Di Era Covid-19 Dan Dampaknya Terhadap Mental Mahasiswa. EduTeach: Jurnal Edukasi Dan Teknologi Pembelajaran. https://doi.org/10.37859/eduteach.v1i2.1987

Wibowo A, \& BNPB, K. P. D. I. dan K. K. (2020). Empat Strategi Pemerintah Atasi COVID-19. Gugus Tugas Percepatan Penanganan COVID-19.

Zahrotunnimah, Z. (2020). Langkah Taktis Pemerintah Daerah Dalam Pencegahan Penyebaran Virus Corona Covid-19 di Indonesia. SALAM: Jurnal Sosial Dan Budaya Syar-I. https://doi.org/10.15408/sjsbs.v7i3.15103 